\title{
Herpes simplex-like infection in a bottlenose dolphin stranded in the Canary Islands
}

\author{
F. Esperón ${ }^{1, *}$, A. Fernández ${ }^{2}$, J. M. Sánchez-Vizcaíno ${ }^{3}$ \\ ${ }^{1}$ Animal Health Research Centre (CISA-INIA), Ctra Algete a El Casar s/n, Madrid, Spain \\ ${ }^{2}$ Institute for Animal Health, Veterinary School, University of Las Palmas de Gran Canaria, Las Palmas, Canary Islands \\ ${ }^{3}$ Department of Animal Health, Faculty of Veterinary Medicine, UCM Madrid, Avda Puerta de Hierro s/n, Madrid
}

\begin{abstract}
A bottlenose dolphin, stranded in the Canary Islands in 2001 exhibited non-suppurative encephalitis. No molecular detection of cetacean morbillivirus (CeMV) was found, but a herpesviralspecific band of $250 \mathrm{bp}$ was detected in the lung and brain. The sequenced herpesviral PCR product was compared with GenBank sequences, obtaining $98 \%$ homology (p-distance of 0.02) with Human herpesvirus 1 (herpes simplex virus 1 or HSV-1). This is the first report of a herpes simplex-like infection in a stranded dolphin.
\end{abstract}

KEY WORDS: Bottlenose dolphin $\cdot$ Herpesvirus $\cdot$ Herpes simplex virus $\cdot$ Infectious diseases $\cdot$ Zoonosis

\section{INTRODUCTION}

Herpesviral infections are very common in a wide variety of hosts, mainly vertebrates, including birds, reptiles and mammals (McGeoch et al. 2006). Herpesviruses are double-stranded DNA viruses, with an icosahedral form and a genome length that varies from 120 to $230 \mathrm{kbp}$ (Roizman 1996).

There are few reports of herpesviral infections in marine mammals. Most reports are morphological, where the diagnosis is based on gross pathology (Baker 1992), histopathology and immunohistochemistry (Kennedy et al. 1992) or transmission electron microscopy (TEM) (Martineau et al. 1988, Van Bressem et al. 1994). So far, no cetacean herpesviruses have been isolated with cell culture; thus, molecular diagnostic tools are essential to establish their taxonomic classification. Amplification of conserved DNA regions within the herpesvirus polymerase gene (VanDevanter et al. 1999) and terminase gene (Hargis et al. 1999) has been possible using universal PCRs. Further sequencing of the resultant amplicons has provided new reports of alphaherpesvirus in the bottlenose dolphin Tursiops truncatus (Blanchard et al. 2001, Manire et al. 2006, Smolarek-Benson et al. 2006), and gammaherpesvirus in bottlenose dolphin, Risso's dolphin Grampus griseus, the dwarf sperm whale Kogia sima and Blainville's beaked whale Mesoplodon densirostris (Saliki et al. 2006, Smolarek-Benson et al. 2006).

The Canary Islands are a privileged coastal system in terms of cetacean diversity and abundance, with more than 30 cetacean species (Stephanis \& Urkiola 2007). This is due to their strategic location in the migratory routes and their oceanographic characteristics. The short continental shelf of the islands favours a close approach to the coast and the establishment of resident populations such as bottlenose dolphin, the short-finned pilot whale Globicephala macrorhynchus and the sperm whale Physeter macrocephalus. As a consequence, cetaceans can be observed close to the coast and are exposed to industrial, agricultural and urban sewage sources.

A retrospective study was performed to detect herpesviral sequences in banked tissue of stranded dolphins in the Canary Islands. The present report describes the first case of a herpes simplex-like infection in a bottlenose dolphin.

\section{MATERIALS AND METHODS}

Samples. An adult male bottlenose dolphin stranded dead on Tenerife (Canary Islands) in 2001 was analyzed in this study. Gross pathology showed emacia- 
tion and the main histopathology finding was mild, non-suppurative encephalitis. The lung showed verminous pneumonia. Samples from brain, liver and lung were frozen at $-80^{\circ} \mathrm{C}$ until further analysis. In order to determine the presence of viral agents related to encephalitis in marine mammals, an RT-PCR for morbillivirus and a PCR for herpesvirus were performed on brain, liver and lung samples.

RNA and DNA extraction. Prior to nucleic acid extraction, $1 \mathrm{~g}$ of tissue was manually macerated in $10 \mathrm{ml}$ of sterile phosphate-buffered saline (PBS) and subsequently centrifuged at $900 \times g$ for $15 \mathrm{~min}$. Supernatants from the macerates were collected. RNA extraction was carried out from a $100 \mu$ l macerated sample using the TriPure Reagent (Roche Diagnostics) method, following the manufacturer's instructions. DNA extraction was performed with High Pure Template Preparation Kit (Roche Diagnostics), following the manufacturer's instructions. Extracted DNA was eluted in $50 \mu \mathrm{l}$ of sterile water.

PCR. Molecular detection of cetacean morbillivirus (CeMV) was performed by 1-step RT-PCR, which amplifies 426 bp within a conserved region in the phosphoprotein gene (Reidarson et al. 1998). Two negative controls and a positive control of dolphin morbillivirus (DMV), MUC strain, provided by T. Barrett (Institute for Animal Health, Pirbright Laboratory, UK) were included.

A universal nested PCR previously developed (Vandevanter et al. 1996) that amplifies a conserved region within the polymerase gene of the Herpesviridae family was applied. To prevent carryover contamination, 2 negative controls were added for each reaction, one for DNA extraction and the other for $\mathrm{PCR}$ reaction. A positive control of Human herpesvirus 1 strain $\mathrm{F}$, was provided by $\mathrm{S}$. Gómez-Sebastián (National Institute for Agriculture and Food Scientific Research and Technology, INIA, Madrid, Spain). The expected size of the amplicon for herpesvirus ranged between 215 and 315 bp.

Products of both PCRs were electrophoresed in $2 \%$ agarose gels, stained with Sybr ${ }^{\circledR}$ Green. The specific bands were excised and sequenced. Purification of DNA products in positive samples was performed using a GFX PCR DNA and Gel Band Purification Kit (Amersham Biosciences), following the manufacturer's instructions. Sequencing was done in triplicate using an ABI Prism 3100 sequencer (Applied Biosystems).

Sequenced products were compared with sequences available in GenBank using the BLAST search. The sequence obtained was aligned using the Clustal W software. Phylogenetic analysis was performed using MEGA 4.0 software (Tamura et al. 2007). Neighbor-joining was employed to infer the tree topology. The reliability of the trees was tested by bootstrapping 1000 replicates generated with a random seed. The matrix distances were calculated based on p-distance. The consensus tree is represented in Fig. 1.

\section{RESULTS AND DISCUSSION}

A specific band was not observed in the RT-PCR for morbillivirus. In contrast, a herpesviral specific band of $250 \mathrm{bp}$ was detected in lung and brain. The product was sequenced and compared with GenBank published sequences, obtaining $98 \%$ homology ( $\mathrm{p}$-distance of 0.02) with Human herpesvirus 1 (herpes simplex virus 1 or HSV-1). Other similarities occurred with Human herpesvirus 2 (herpes simplex virus 2 or HSV-2) and positive control (F strain of HSV-1), with p-distances of 0.13 and 0.14 , respectively. The PCR method used in this study for herpesvirus detection was developed from a conserved fragment of herpesvirus polymerase gene, and the sequences from this region have been found to be unique to each herpesvirus species (VanDevanter et al. 1996). In addition, this PCR method has been used to detect and classify novel sequences of herpesvirus in different hosts such as

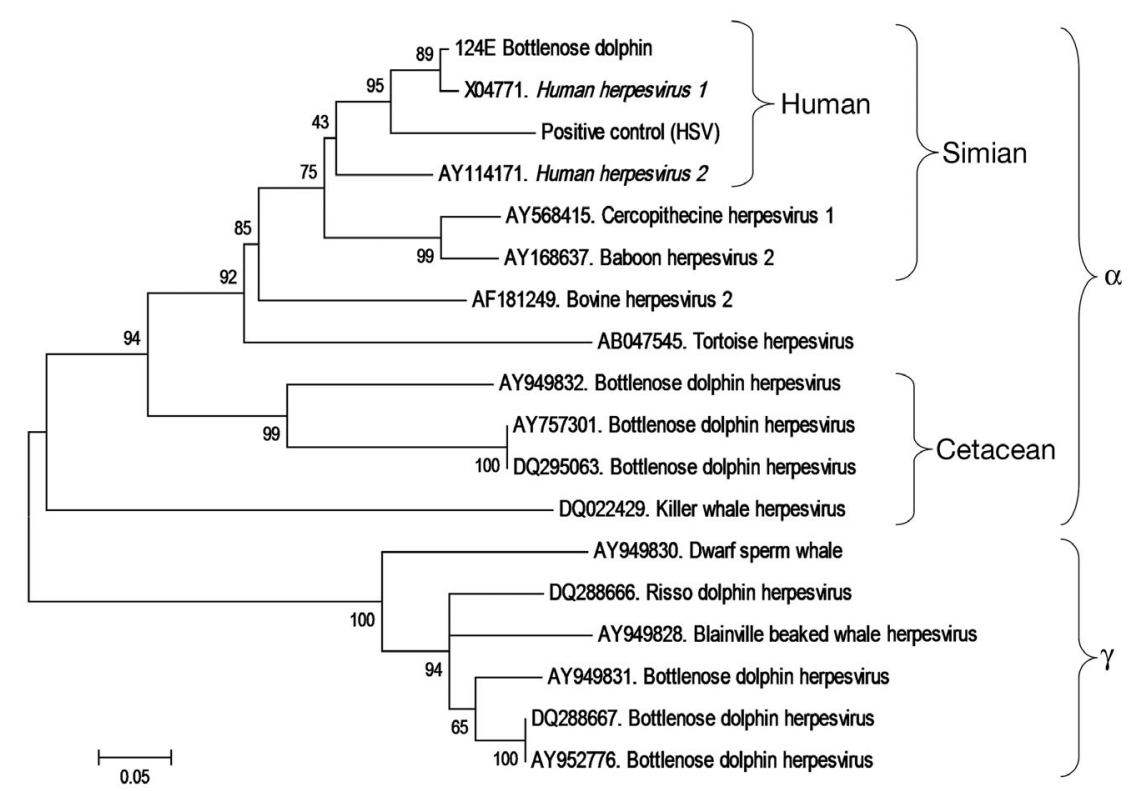

Fig. 1. Neighbor-joining phylogram of 18 selected sequences from cetacean alpha- and gammaherpesvirus and other phylogenetically related alphaherpesviruses. The name of the sequence shows the GenBank Accession Number and host species. The GenBank Accession Number of the isolate of this study: EU003440 
cetaceans (Blanchard et al. 2001, Saliki et al. 2006, Smolarek-Benson et al. 2006) and reptiles (Govett et al. 2005, Johnson et al. 2005, Wellehan et al. 2005). Due to the high homology found between the sequence obtained in the present study and the sequence for HSV-1 published in GenBank (X04771), it could be concluded that the first may be considered an HSV-like sequence.

On the other hand, p-distances among the sequence obtained from this bottlenose dolphin and others previously described in GenBank for cetacean herpesviruses ranged between 0.45 and 0.66 for alphaherpesviruses and 0.63 and 0.69 for gammaherpesviruses. Most of the molecular reports of cetacean herpesviruses are limited to cutaneous and mucosal infections (Saliki et al. 2006, Smolarek-Benson et al. 2006). Very few data are available about herpesviral systemic infections in cetaceans; however, one case of encephalitis in a harbour porpoise has been reported (Kennedy et al. 1992). The diagnosis of herpesviral encephalitis has been based on immunohistochemistry, showing cross reaction with HSV and bovine herpesvirus. Unfortunately these data are insufficient to identify the viral species implicated in this case. In addition, 2 cases of generalized systemic herpesviral infections in bottlenose dolphins (Blanchard et al. 2001) have been described, and 2 novel sequences from herpesviral polymerase genes were detected. Main pathological findings were observed in the lymphoid system, heart, skin and adrenal glands. These sequences showed a close homology with those described in other bottlenose dolphins with skin diseases (SmolarekBenson et al. 2006) and therefore they may be considered as the same viral species.

Although it is widely demonstrated that viruses are species-specific, alphaherpesviruses are considered the least specific among the Herpesviridae family. Most of the reports about HSV in species other than humans are restricted to non-human primates such as chimpanzees (McClure et al. 1980), gorillas (Heldstab et al. 1981), common marmosets (Mätz-Rensing et al. 2003), saki monkeys (Schrenzel et al. 2003), gibbons (Landolfi et al. 2005) and orangutans (Kik et al. 2005). Only a few descriptions of HSV infections in nonprimate hosts are available; they describe infections in a chinchilla (Wohlsein et al. 2002), a rabbit (Grest et al. 2002) and an African pygmy hedgehog (Allison et al. 2002).

The presence of an HSV-like sequence of possible human origin in a bottlenose dolphin has not been previously described. The small continental shelf of the Canary Archipelago favours the proximity of different cetacean populations to the coast, and this predisposes them to greater exposure to pesticides, industrial pollutants and urban wastes. As the human population increases, the environmental release of human micro- organisms through urban sewage also increases, as has been demonstrated for enterovirus and norovirus (Payment et al. 2001, Haramoto et al. 2006). This could be a potential risk for cetacean populations. In addition, the role of faecal bacteria from Hong Kong's human sewage as the cause of death of stranding dolphins has been described previously (Parsons \& Jefferson 2000).

Although an HSV-like sequence has been detected in the brain of a stranded bottlenose dolphin, the role of this virus as an etiologic agent of mild nonsuppurative encephalitis has not yet been determined. To resolve this question, immunohistochemical or TEM detection should be performed; unfortunately there was not adequate sample to perform these assays. The presence of herpesviruses in stranded cetaceans from the Canary Islands and their role in cetacean health status and stranding causes will be evaluated in further studies.

Acknowledgements. The authors thank R. Cabrera and E. Neves for their technical support. This study was financed by the project of the National Researching Plan, REN 200204162-C02-02.

\section{LITERATURE CITED}

Allison N, Chang TC, Steele KE, Hilliard JK (2002) Fatal herpes simplex infection in a pygmy African hedgehog (Atelerix albiventris). J Comp Pathol 126:76-78

Baker JR (1992) Skin disease in wild cetaceans from British waters. Aquat Mamm 18:27-32

> Blanchard TW, Santiago NT, Lipscomb TP, Garber RL, Mcfee WE, Knowles S (2001) Two novel alphaherpesviruses associated with fatal disseminated infections in Atlantic bottlenose dolphins. J Wildl Dis 37:297-305

> Govett PD, Harms CA, Johnson AJ, Latimer KS and others (2005) Lymphoid follicular cloacal inflammation associated with a novel herpesvirus in juvenile alligators (Alligator mississippiensis). J Vet Diagn Invest 17:474-479

Grest P, Albicker P, Hoelzle L, Wild P, Pospischil A (2002) Herpes simplex encephalitis in a domestic rabbit (Oryctolagus cuniculus). J Comp Pathol 126:308-311

Haramoto E, Katayama H, Oguma K, Yamashita H, Tajima A, Nakajima H, Ohgaki S (2006) Seasonal profiles of human noroviruses and indicator bacteria in a wastewater treatment plant in Tokyo, Japan. Water Sci Technol 54: 301-308

> Hargis AM, Ginn PEJ, Mansell EKL, Garber RL (1999) Ulcerative facial and nasal dermatitis and stomatitis in cats associated with feline herpesvirus 1. Vet Dermatol 10: 267-274

Heldstab A, Ruëdi D, Sonnabend W, Deinhardt F (1981) Spontaneous generalized Herpesvirus hominis infection of a lowland gorilla (Gorilla gorilla gorilla). J Med Primatol 10:129-135

Johnson AJ, Pessier AP, Wellehan JF, Brown R, Jacobson ER (2005) Identification of a novel herpesvirus from a California desert tortoise (Gopherus agassizii). Vet Microbiol 111:107-116

Kennedy S, Lindstedt IJ, McAliskey MM, McConnell SA, McCullough SJ (1992) Herpesviral encephalitis in a 
harbor porpoise (Phocoena phocoena). J Zoo Wildl Med 23:374-379

Kik MJ, Bos JH, Groen J, Dorrestein GM (2005) Herpes simplex infection in a juvenile orangutan (Pongo pygmaeus pygmaeus). J Zoo Wildl Med 36:131-134

Landolfi JA, Wellehan JFX, Johnson AJ, Kinsel MJ (2005) Fatal human herpesvirus type 1 infection in a whitehanded gibbon (Hylobates lar). J Vet Diagn Invest $17: 369-371$

Manire CA, Smolarek KA, Romero CH, Kinsel MJ, Clauss TM, Byrd L (2006) Proliferative dermatitis associated with a novel alphaherpesvirus in an Atlantic bottlenose dolphin (Tursiops truncatus). J Zoo Wildl Med 37: $174-181$

Martineau D, Lagace A, Bèland P, Higgens R, Armstrong D, Shugart LR (1988) Pathology of stranded beluga whales (Delphinapterus leucas) from the St. Lawrence Estuary, Québec. Canada. J Comp Pathol 98:287-311

Mätz-Rensing K, Jentsch KD, Rensing S, Langenhuyzen S, Verschoor E, Niphuis H, Kaup FJ (2003) Fatal Herpes simplex infection in a group of common marmosets (Callithrix jacchus). Vet Pathol 40:405-411

McClure HM, Swenson RB, Kalter SS, Lester TL (1980) Natural genital Herpesvirus hominis infection in chimpanzees (Pan troglodytes and Pan paniscus). Lab Anim Sci 30: 895-900

McGeoch DJ, Rixon FJ, Davison AJ (2006) Topics in herpesvirus genomics and evolution. Virus Res 117:90-104

Parsons ECM, Jefferson TA (2000) Post-mortem investigations on stranded dolphins and porpoises from Hong Kong waters. J Wildl Dis 36:342-356

Payment P, Plante R, Cejka P (2001) Removal of indicator bacteria, human enteric viruses, Giardia cysts, and Cryptosporidium oocysts at a large wastewater primary treatment facility. Can J Microbiol 47:188-193

Reidarson TH, Mcbain J, House C, King DP and others (1998) Morbillivirus infection in stranded common dolphins from the Pacific Ocean. J Wildl Dis 34:771-776

Editorial responsibility: Michael Moore, Woods Hole, Massachusetts, USA
Roizman B (1996) Herpesviridae. In: Fields BN, Knipe DM, Howley PM (eds) Fields virology, 3rd edn. LippincottRaven Publishers, Philadelphia, PA, p 2221-2230

Saliki JT, Cooper EJ, Rotstein DS, Caseltine SL and others (2006) A novel gammaherpesvirus associated with genital lesions in a Blainville's beaked whale (Mesoplodon densirostris). J Wildl Dis 42:142-148

Schrenzel MD, Osborn KG, Shima A, Klieforth RB, Maalouf GA (2003) Naturally occurring fatal herpes simplex virus 1 infection in a family of white-faced saki monkeys (Pithecia pithecia pithecia). J Med Primatol 32:7-14

Smolarek-Benson KA, Manire CA, Ewing RY, Saliki JT, Townsend FI, Ehlers B, Romero CH (2006) Identification of novel alpha- and gammaherpesviruses from cutaneous and mucosal lesions of dolphins and whales. J Virol Methods 136:261-266

Stephanis R, Urkiola E (2007) Collisions between ships and cetaceans in Spain. Available at: www.iwcoffice.org/ _documents/sci_com/SC58docs/SC-58-BC5.pdf

Tamura K, Dudley J, Nei M, Kumar S (2007) MEGA4: Molecular Evolutionary Genetics Analysis (MEGA) software version 4.0. Mol Biol Evol 24:1596-1599

- Van Bressem MF, Van Waerebeek K, Garcia-Godos A, Dekegel D, Pastoret PP (1994) Herpes-like virus in dusky dolphins, Lagenorhynchus obscurus, from coastal Peru. Mar Mamm Sci 10:354-359

> VanDevanter DR, Warrener P, Bennett L, Schultz ER, Coulter S, Garber RL, Rose TM (1996) Detection and analysis of diverse herpesviral species by consensus PCR. J Clin Microbiol 34:1666-1671

- Wellehan JF, Johnson AJ, Latimer KS, Whiteside DP and others (2005) Varanid herpesvirus 1: a novel herpesvirus associated with proliferative stomatitis in green tree monitors (Varanus prasinus). Vet Microbiol 105:83-92

Wohlsein P, Thiele A, Fehr M, Haas L, Henneicke K, Petzold DR, Baumgärtner W (2002) Spontaneous human herpes virus type 1 infection in a chinchilla (Chinchilla lanigera $f$. dom.). Acta Neuropathol 104:674-678

Submitted: September 27, 2007; Accepted: March 6, 2008 Proofs received from author(s): May 5, 2008 